\title{
MODIFICATIONS OF PHYSICAL PROPERTIES OF COCONUT OIL AND ANHYDROUS MILK FAT AS A RESULT OF BLENDING
}

\author{
A. Soós ${ }^{\mathrm{a} *}$, L. SOMOGYI ${ }^{\mathrm{a}}$, G. JAKAB ${ }^{\mathrm{a}}$, and B. IMRE ${ }^{\mathrm{b}}$, \\ ${ }^{a}$ Department of Grain and Industrial Crop Technology, Faculty of Food Science, Corvinus University of Budapest, \\ H-1118 Budapest, Villányi út 29-43. Hungary \\ ${ }^{\mathrm{b}}$ Faculty of Chemical Technology and Biotechnology of Budapest University of Technology and Economics, \\ H-1111 Budapest, Müegyetem rkp. 3. Hungary
}

(Received: 10 April 2014; accepted: 21 July 2014)

\begin{abstract}
The role of fats in food technology is mainly to develop the desired consistency. The simplest way to reach this goal is the blending of different fats. The aim of our work was to study the solidification and melting properties of blends of coconut oil and anhydrous milk fat. Pure fats and their $25-75 \%, 50-50 \%$, and $75-25 \%$ blends were investigated. Melting profile and isotherm crystallization were measured by pNMR. Non-isotherm melting and solidification were detected by differential scanning calorimetry (DSC). Possible applications of the blends were established. Results show that AMF and coconut oil has limited miscibility, which is dependent on the temperature. Below $22{ }^{\circ} \mathrm{C} A M F$ is the softening component, above $22^{\circ} \mathrm{C}$ the effect is inverse. Coconut oil accelerates solidification of AMF, however, basic crystal forms of AMF remained.
\end{abstract}

Keywords: coconut oil, anhydrous milk fat, melting properties, solidification, fat blend

Coconut oil is one of the most widely used fats in the food industry. Due to its melting and crystallization characteristics, margarine and shortening production as well as confectionary industry consider coconut oil as a basic material in product formulation. Since these kinds of products consist of other fat materials, it is important to study the counter relationship of coconut oil and other fats when they are blended. In our study, coconut oil and anhydrous milk fat (AMF) were blended in different ratios, the modifications of the most important physical properties, melting profile and solidification, were studied. Our earlier studies (Somogyi et al., 2009) indicated that the modification of these parameters should be highly affected by the restricted miscibility of coconut oil and AMF.

\section{Materials and methods}

\subsection{Materials}

Anhydrous milk fat was gathered from local confectionary factory (Bonbonetti Choco $\mathrm{Kft}$ ). The origin of the coconut oil was commercial wholesaler (Barco CO). Five hundred $\mathrm{cm}^{3}$ of the materials were heated up to $80^{\circ} \mathrm{C}$ in order to eliminate crystal structure. Pure fat samples and $25-75 \%, 50 \%-50 \%$, and $75-25 \%$ blends of $A M F$ and coconut oil were prepared in liquid state in volumetric flasks, and then cooled to $5^{\circ} \mathrm{C}$ and kept in refrigerator until measurements were conducted.

\footnotetext{
* To whom correspondence should be addressed.

Phone: +36-1-483-6345; fax: +36-1-482-6355; e-mail:anita.soos@uni-corvinus.hu
} 


\subsection{Methods}

Fatty acid composition of pure fats was analysed by gas chromatograph (GC) according to the methods based on MSZ ISO 5508:1992. The type of the apparatus was HP 5890 GC system, with SGE BPX 70 column with parameters $50 \mathrm{~m} \times 0.22 \mathrm{~mm} \times 0.25 \mu \mathrm{m}$. Heating was from $150{ }^{\circ} \mathrm{C}$ to $210{ }^{\circ} \mathrm{C}$ (with $1.3{ }^{\circ} \mathrm{C} \mathrm{min}-1$ heating rate). Pressure: 14 psi, injector: $250{ }^{\circ} \mathrm{C}$ split, split ratio: 100:1. Detector: $250^{\circ} \mathrm{C}$, FID. The carrier gas was hydrogen, the flow rate was $0.6 \mathrm{~cm}^{3} \mathrm{~min}^{-1}$, injection pressure was 0.965 bars. Identification of fatty acids was based on the retention times using fatty acid methyl ester standards.

Solidification was detected by measuring solid fat content with pNMR (Bruker Minispec $120)$ apparatus. The measurement, based on the method reported by CAMPOS and co-workers (2010) was modified as follows: samples were heated up to $80^{\circ} \mathrm{C}$ and kept there for $15 \mathrm{~min}$. The completely liquid samples were adjusted in NMR tubes and put into a $5{ }^{\circ} \mathrm{C}$ thermostat. Measurements were done every $5 \mathrm{~min}$ for $90 \mathrm{~min}$. Three parallel measurements had been done and average values were reported.

Slip melting point (SMP) was measured to characterize the melting properties of the samples by the official standard method (MSZ EN ISO 6321:2002).

The melting profile of the fats was established by the solid fat content curves (SFC) by means of pNMR apparatus (Bruker Minispec 120, Bruker, Germany) following the AOCS (2005) method (AOCS Cd 16b-93). The samples were heated to $80^{\circ} \mathrm{C}$ and held for $15 \mathrm{~min}$ in order to eliminate crystal memory. All samples were kept at $60^{\circ} \mathrm{C}$ for 15 min, cooled down to $0^{\circ} \mathrm{C}$, and maintained at this temperature for $60 \mathrm{~min}$. Finally, before measurements, samples were held at the temperature of the measurements for 30-35 min. Temperatures were: 10,20 , 30,40 , and $50{ }^{\circ} \mathrm{C}$. Three parallel measurements were done and average values were reported.

Differential scanning calorimetry (DSC) measurements were done in order to follow the solidification and melting phenomena during cooling and heating. Of each sample $20-25 \mathrm{mg}$ was put into $100 \mu \mathrm{l}$ alumina sample holders. The temperature program was as follows: samples were cooled to $0{ }^{\circ} \mathrm{C}$ by $1{ }^{\circ} \mathrm{C} \mathrm{min}-1$ and kept at this temperature for 10 min. Heating was performed from $0{ }^{\circ} \mathrm{C}$ up to $80{ }^{\circ} \mathrm{C}$ at $1{ }^{\circ} \mathrm{C} \mathrm{min}$. Samples were kept at this temperature for $30 \mathrm{~min}$, and then the cooling program was applied at $1{ }^{\circ} \mathrm{C} \min ^{-1}$ to $-20^{\circ} \mathrm{C}$ and kept under this condition for $10 \mathrm{~min}$. Finally, the samples were heated up to ambient temperature. Measurements were done during the constant speed heating and cooling processes. Results were elaborated by Callisto Processing 1.076 computer program using linear base line. Heat flow and enthalpy of exotherm and endotherm peaks were recorded and calculated.

\section{Results and discussions}

Fatty acid compositions of the samples are shown in Table 1. AMF contained a great variety of fatty acids. Our results are consistent with the literature data (e.g. Firestone, 1999; O'Brien, 2009). Saturated fatty acids covered more than $70 \%$ of the total. Palmitic acid, oleic acid, myristic acid, and stearic acid were the dominant compounds. C4:0-C12:0 fatty acids were found in $12 \%$, as characteristic to the AMF. Coconut oil contained lauric acid (45.7\%) and myristic acid (18.5\%) as the dominant components. The total of the saturated fatty acids exceeded $90 \%$. These findings are in accordance with the well-known literature data (e.g.: MARINA et al., 2009). 
Table 1. Fatty acid composition (\%) of coconut oil and anhydrous milk fat

\begin{tabular}{|c|c|c|}
\hline \multicolumn{3}{|c|}{ Fatty acid composition (\%) } \\
\hline Fatty acid & Coconut oil & AMF \\
\hline $\mathrm{C} 4: 0$ & 0.0 & 1.9 \\
\hline C6:0 & 1.3 & 1.5 \\
\hline C8:0 & 6.7 & 1.1 \\
\hline $\mathrm{C} 10: 0$ & 5.6 & 2.8 \\
\hline $\mathrm{C} 10: 1$ & 0.0 & 0.3 \\
\hline $\mathrm{C} 12: 0$ & 45.9 & 4.2 \\
\hline $\mathrm{C} 12: 1$ & 0.0 & 0.1 \\
\hline $\mathrm{C} 13: 0$ & 0.0 & 0.1 \\
\hline $\mathrm{C} 13: 1$ & 0.0 & 0.1 \\
\hline $\mathrm{C} 14: 0$ & 18,5 & 12.5 \\
\hline C14:1 & 0.0 & 1.4 \\
\hline $\mathrm{C} 15: 0$ & 0.0 & 1.2 \\
\hline $\mathrm{C} 15: 1$ & 0.0 & 0.3 \\
\hline $\mathrm{C} 16: 0$ & 9.5 & 34.8 \\
\hline $\mathrm{C} 16: 1 \mathrm{tr}$ & 0.0 & 0.00 \\
\hline $\mathrm{C} 16: 1$ cis & 0.0 & 1.7 \\
\hline $\mathrm{C} 17: 0$ & 0.0 & 0.6 \\
\hline $\mathrm{C} 17: 1$ & 0.0 & 0.2 \\
\hline C18:0 & 3.1 & 10.7 \\
\hline $\mathrm{C} 18: 1 \mathrm{tr}$ & 0.00 & 0.53 \\
\hline C18:1cis & 7.0 & 19.0 \\
\hline $\mathrm{C} 18: 2 \mathrm{tr}$ & 0.00 & 0.82 \\
\hline $\mathrm{C} 18: 2$ cis & 1.7 & 1.4 \\
\hline $\mathrm{C} 18: 3 \mathrm{tr}$ & 0.00 & 0.00 \\
\hline C18:3cis & 0.0 & 0.4 \\
\hline C20:0 & 0.1 & 0.5 \\
\hline C20:1 & 0.0 & 0.1 \\
\hline C20:2 & 0.0 & 0.0 \\
\hline $\mathrm{C} 22: 0$ & 0.1 & 0.0 \\
\hline $\mathrm{C} 22: 1$ & 0.0 & 0.0 \\
\hline $\mathrm{C} 24: 0$ & 0.0 & 0.1 \\
\hline $\mathrm{C} 24: 1$ & 0.0 & 0.0 \\
\hline not id. & 0.5 & 1.65 \\
\hline Sum & 100.0 & 100.0 \\
\hline Summa trans & 0.00 & 1.35 \\
\hline
\end{tabular}


Results of isotherm crystallization of the samples are demonstrated in Figure 1A, where the solid fat content in percentages is shown as a function of time in min. Since relative standard deviations were less than $5 \%$ in each case, average values were presented. Crystallization curves show that approximately within $40 \mathrm{~min}$ fats solidified almost completely. It is also clear that AMF solidified in a two-step mechanism and the other samples show different phenomena. This two-step solidification of AMF has been reported by other authors (HERRERA et al., 1999; WiKIng et al., 2001) as well. The slope of the curves became higher for AMF if the amount of coconut oil in the blend exceeded 50\%. Additionally, the equilibrium SFC decreased by the increasing amount of AMF in the blend. Equilibrium solid fat content of the blends was closer to the pure AMF, indicating that coconut oil does not raise the solid fat content strongly in the presence of AMF. This finding is attributed to the medium chain fatty acids of coconut oil that have relatively low melting temperature: $44.2{ }^{\circ} \mathrm{C}$ and $53.9{ }^{\circ} \mathrm{C}$ for lauric acid and myristic acid, respectively (Gunstone, 1986). This finding is a possible indicator of retarded miscibility (BRAIPSON-DANTHINE, 2006).

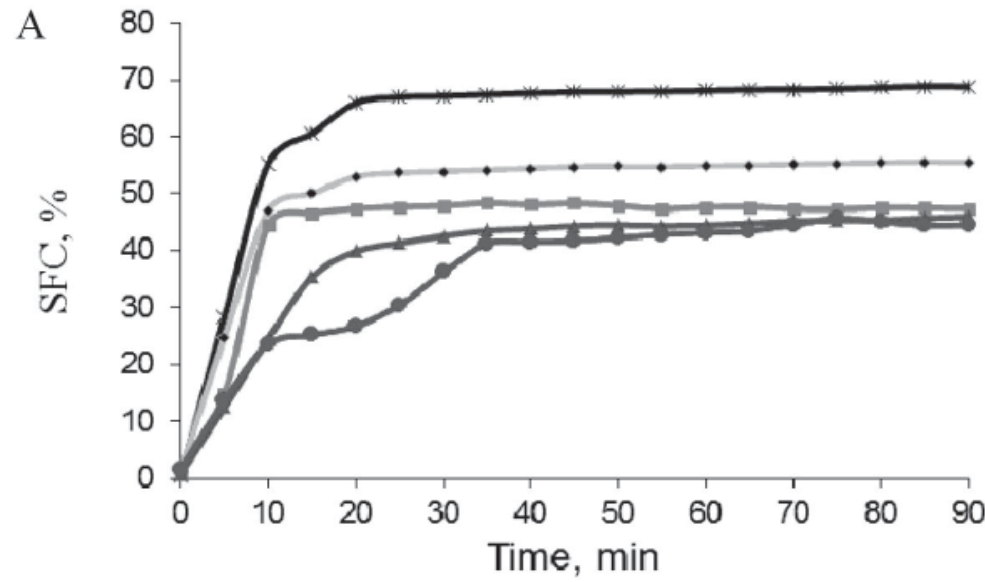

Fig. 1A. Isotherm crystallization of pure fats and blends

$*$ Coconut oil; $\longrightarrow: 25-75 \%$ AMF-coconut oil; - - $: 50-50 \%$ AMF-coconut oil;
$\longrightarrow$ - $75-25 \%$ AMF-coconut oil; $\longrightarrow$ - AMF

In Figure 1B cooling thermograms of the samples are shown. Coconut oil had a great exotherm peak at $9.5^{\circ} \mathrm{C}$ (enthalpy: $-90 \mathrm{~J} \mathrm{~g}^{-1}$ ). Similar thermogram was detectable in case of $25-75 \%$ AMF-coconut oil blend. On the other hand, the 50-50\% and 75-25\% AMF-coconut oil blends showed analogous thermograms as AMF. Sample of 50-50\% AMF-coconut oil had a wide exotherm peak with low heat content beside the bigger peak. While the latter is characteristic of the coconut oil, the other may contain the tryglicerides both of AMF and coconut oil. Low energy indicates less stability. This phenomenon is associated with the limited miscibility of AMF and coconut oil. 


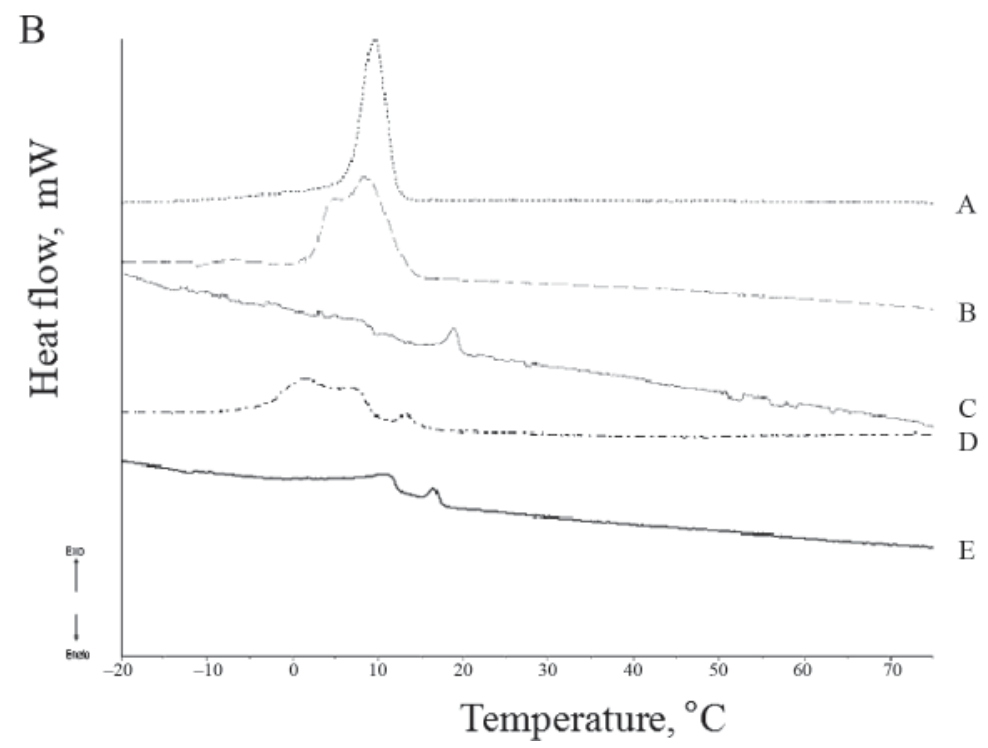

Fig. 1B. Differential scanning calorimetry cooling curves of pure fats and blends.

A: Coconut oil; B: 25-75\% AMF-coconut oil; C: 50-50\% AMF-coconut oil; D: 75-25\% AMF-coconut oil; $\mathrm{E}: \mathrm{AMF}$

Melting properties of the investigated samples are summarized in Figure 2. In Figure 2A slip melting points of the samples are shown. Results proved that AMF had the highest and coconut oil the lowest SMP value. Blends presented decreasing SMP values according to the increasing amount of coconut oil $\left(31.5,27,25.3,24.7\right.$, and $23.7^{\circ} \mathrm{C}$, respectively). Solid fat content of the samples are shown in Figure 2B. From the figure it can be seen that coconut oil had the highest and AMF the lowest SFC value at low temperature. Coconut oil and the blends melted rather fast. Individual SFC values of the blends were close to each other and the shape of the SFC curve was similar. Similar results were reported by LIEW and co-workers (2001). SFC curve of the AMF performed a characteristic plateau between $20^{\circ} \mathrm{C}$ and $25^{\circ} \mathrm{C}$. At higher temperatures, AMF and 50-50\%, 75-25\% (AMF-Co) contained more solids than pure coconut oil and $25-75 \%$ samples.

SFC curves crossed each other and this indicates the limited miscibility of AMF and coconut oil and the existence of eutectic phenomena. From the results we could state that in the temperature range below $20-22{ }^{\circ} \mathrm{C} A M F$ is the softening component, but above $25{ }^{\circ} \mathrm{C}$ it is the coconut oil.

The eutectic behaviour is highly important in food application. Producers must carefully apply these blends, since the texture of the final product could undergo undesirable changes. Melting thermograms measured by DSC are shown in Figure 2C. Coconut oil had a double peak at $22{ }^{\circ} \mathrm{C}$ (enthalpy: $90 \mathrm{~J} \mathrm{~g}^{-1}$ ), AMF showed more complex crystal structure. Three smaller endotherm peaks were characteristic of melting. Total enthalpy of them was $57 \mathrm{~J} \mathrm{~g}^{-1}$. These three peaks were detectable also for $75-25 \%$ and $50-50 \%$ blends, but the position and the enthalpy values were slightly different. Blend of $25 \%$ AMF and $75 \%$ coconut oil had only two peaks that were similar to the pure coconut oil, and the sum of the enthalpies was higher $\left(67 \mathrm{~J} \mathrm{~g}^{-1}\right)$. 


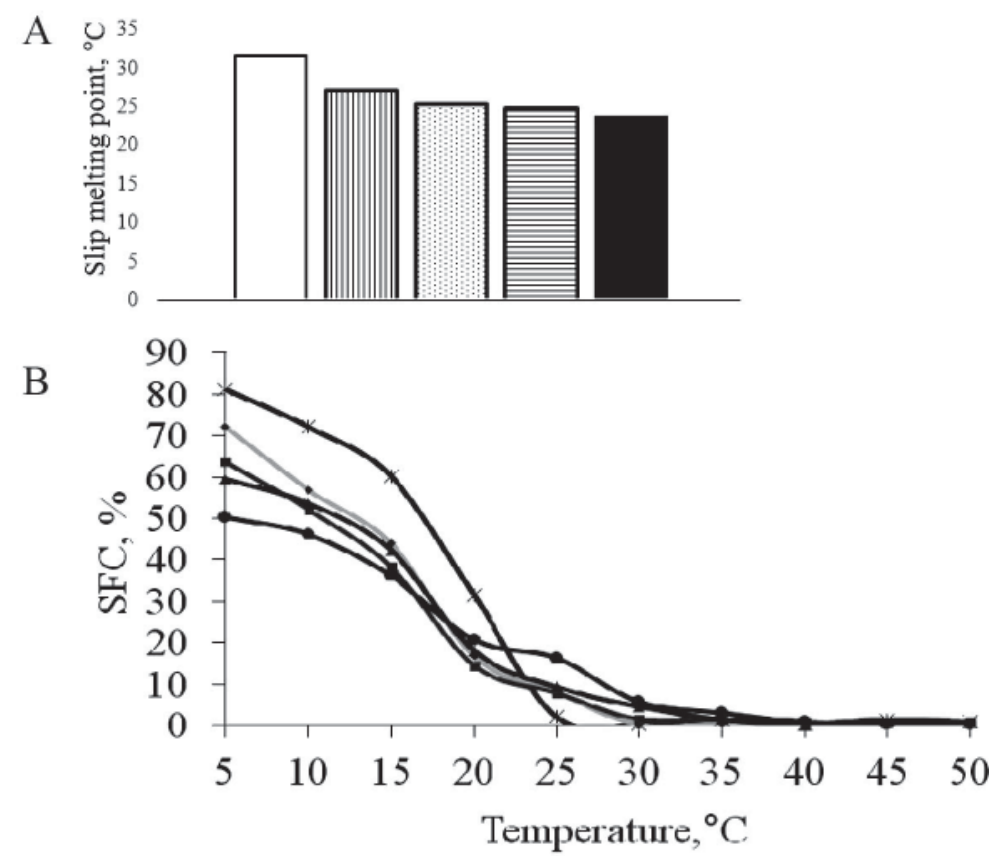

C

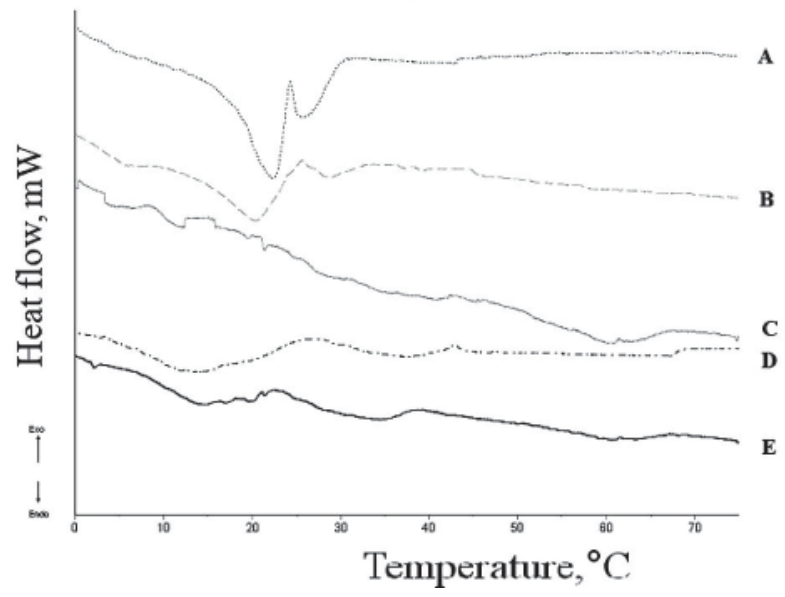

Fig. 2A. Slip melting points of pure fats and blends.

$\square:$ AMF; $\mathbb{m}: 75-25 \%$ AMF-coconut oil; $6:$ : 50-50\% AMF-coconut oil; 目:25-75\% AMF-coconut oil; $\square$ : coconut oil

Fig. 2B. SFC curves of pure fats and blends.

* :Coconut oil; $\neg-25-75 \%$ AMF-coconut oil; - - $50-50 \%$ AMF-coconut oil; $\longrightarrow$ : 75-25\% AMF-coconut oil; - - : AMF

Fig. 2C. Differential scanning calorimetry melting curves of pure fats and blends. A: Coconut oil, B: 25-75\% AMF-coconut oil, C: 50-50\% AMF-coconut oil, D: $75-25 \%$ AMF-coconut oil, E: AMF 


\section{Conclusions}

Based on the results the following conclusions can be drawn:

Coconut oil accelerates the solidification of AMF due to the fast polymorph transition $(\beta$ ' to $\beta)$. This is proved by the fact that in the presence of coconut oil the two-step crystallization is eliminated. Additionally, the velocity of solidification increases by the increasing amount of coconut oil. During crystallization the characteristic crystal forms of AMF remain. We could conclude that AMF served the pattern of crystallization.

Melting process is governed by AMF, because the melting profiles of the blends are similar to the pure AMF. This conclusion is supported by the fact that crystal forms of AMF are present during melting as it is detected by DSC.

The AMF-coconut oil blends show temperature-dependent eutectic phenomenon. Below $22^{\circ} \mathrm{C}$ AMF is the softening component, above $22^{\circ} \mathrm{C}$ coconut oil has the similar effect. Despite that AMF has higher SMP, AMF is considered as harder fat only above $22{ }^{\circ} \mathrm{C}$. Individual values of solid fat content prove that below $22^{\circ} \mathrm{C}$ coconut oil has more solids than AMF.

As practical conclusions it can be stated that beneficial characteristics of coconut oil can be utilized for products that need cooled handling until consumption, e.g. dairy desserts, because these fats are completely miscible at low temperature.

This work was supported by the TÁMOP 4.2.1./B09/01/KMR/2010-0005 project.

\section{References}

AOCS (2005): AOCS Official method Cd 16b-93 Solid fat content (SFC) by low-resolution nuclear magnetic resonance; -in: FiRESTONE, D. (Ed.) Official methods and recommended practices of the AOCS. The American Oil Chemists Society, Champaign, IL.

Braipson-Danthine, S. \& Deroanne, C. (2006): Determination of solid fat content (SFC) of binary fat blends and use of these data to predict SFC of selected ternary fat blends containing low-erucic rapeseed oil. J.AOCS, 83, $571-581$.

Campos, R., Narine, S.S. \& Marangoni, A.G. (2010): Effect of cooling rate on the structure and mechanical properties of milk fat. Food Res. Int., 3, 971-981.

FiRestone, D.F. (1999): Physical and chemical characteristics of oils, fats and waxes. AOCS Press, Champaign, IL, USA.

Gunstone, F.D. (1986): Lipid handbook. Chapman and Hall, London, pp. 156-158.

Herrera M.L., De León Gatti, M. \& Hartel, R.W. (1999): A kinetic analysis of crystallization of a milk fat model system. Food Res. Int., 32, 289-298.

Liew, M.Y.B., Ghazali, H.M., Long, K., Lai, O.M. \& Yazid, A.M. (2001): Physical properties of palm kernel oleinanhydrous milk fat mixtures transesterifed using mycelium-bound lipase from Rhizomucor miehei. Food Chem., 72, 447-454.

Marina, A.M., Che Man, Y.B. \& Amin, I. (2009): Virgin coconut oil: Emerging functional food oil. Trends Food Sci. Tech., 20, 481-487.

MSZ ISO (1992): Állati és növényi zsírok és olajok. Zsírsavösszetétel meghatározása gázkromatográfiás módszerrel (Animal and vegetable fats and oils. Analysis by gas chromatography of methyl ester of fatty acids). MSZ ISO 5508:1992.

MSZ EN ISO (2002): Állati és növényi zsírok és olajok. A zsíradékok olvadáspontjának meghatározása nyitott kapilláriscsövekben (csúszáspont). (Animal and vegetable fats and oils. Determination of melting point in open capillary tubes (slip point)). MSZ EN ISO 6321 (2002). 
O’Brien (ED.) (2009): Fats and oils formulating and processing for applications. CRC Press, Boca Raton, USA, 744 pages.

Somogyi, L. \& Soós, A. (2009): Zsírblendek kristályosodási jelenségének tanulmányozása. (Study of crystallizing phenomena of fat blends). Lippay - Ormos - Vas Tudományos Ülésszak. 2009. október 28-30., Budapest

Wiking L., De Graef, V., Rasmussen, M. \& Dewettinck, K. (2001): Relations between crystallisation mechanisms and microstructure of milk fat. Int. Dairy J., 19, 424-430. 